\title{
Agronomic and physiological response of giant reed (Arundo donax L.) to soil salinity
}

\author{
Ida Di Mola, ${ }^{1}$ Gianpiero Guida, ${ }^{2}$ Carmela Mistretta, ${ }^{2}$ Pasquale Giorio, ${ }^{2}$ Rossella Albrizio, ${ }^{2}$ \\ Donato Visconti, ${ }^{1}$ Massimo Fagnano, ${ }^{1}$ Mauro Mori ${ }^{1}$ \\ ${ }^{1}$ Department of Agricultural Sciences, University of Naples, Portici (NA); ${ }^{2}$ National Research Council \\ of Italy (CNR), Institute for Agricultural and Forestry Systems in the Mediterranean (ISAFOM), \\ Ercolano (NA), Italy
}

\begin{abstract}
The soil salinity increase in the Mediterranean basin is one of the consequences of the climate change. The aim of this study was to evaluate the adaptability of giant reed (Arundo donax L.) to salinity, in conditions of higher temperatures, in order to hypothesise the future use of giant reed under these conditions. The trial was carried out in pots under a permanent metal structure, open on the sides and with a clear PE on the top. Four levels of soil salinity in the range 3.3-15.5 dS m$~_{-1}$ were imposed. The stem number of the most stressed treatment was about $45 \%$ lower than the control and also the stem height was lower than in all other treatments. The green and yellow leaf number decreased as the soil salinity increased, and their sum was significantly lower in the two most stressed treatments. Osmotic potential of the leaf sap was not affected by salinity. Leaf water potential and stomatal conductance in the saline treatments were lower than in the control. Assimilation rate showed similar pattern of stomatal conductance. Intrinsic WUE remained almost stable until July and increased
\end{abstract}

Correspondence: Massimo Fagnano, University of Naples, Department of Agricultural Sciences, via Università 100, 80055 Portici (NA), Italy. E-mail: fagnano@unina.it

Key words: Arundo donax; soil salinity; adaptability; yield; ecophysiology; climate changes.

Funding: this work was funded by Italian Ministry of University and Scientific Research (MIUR) with the industrial research project PON01_01966 (EnerBioChem - Integrated agro-industrial chains with high energy efficiency for the development of eco-compatible processes of energy and biochemical production from renewable sources and for land improvement) in the framework of the Operative National Programme 2007-2013.

Received for publication: 19 April 2017.

Revision received: 3 October 2017.

Accepted for publication: 4 October 2017.

CCopyright I. Di Mola et al., 2018

Licensee PAGEPress, Italy

Italian Journal of Agronomy 2018; 13:995

doi:10.4081/ija.2018.995

This article is distributed under the terms of the Creative Commons Attribution Noncommercial License (by-nc 4.0) which permits any noncommercial use, distribution, and reproduction in any medium, provided the original author(s) and source are credited. during August under the most stressful conditions. PSII photochemistry was not affected by soil salinity. Biomass yield was not different from the control until to soil ECe $12.0 \mathrm{dS} \mathrm{m}^{-1}$ : only the most stressed treatment $\left(15.5 \mathrm{dS} \mathrm{m}^{-1}\right)$ caused yield losses $(50 \%)$. Tolerance threshold to salinity was $11.2 \mathrm{dS} \mathrm{m}^{-1}$ and the relative yield losses were $11.6 \%$ per $\mathrm{dS} \mathrm{m} \mathrm{m}^{-1}$.

\section{Introduction}

In the perspective of climate changes, new cropping systems have to be developed by integrating energy, food, and animal feed production. In this framework, the low-input perennial species are considered the more suitable crops for supplying biomass to produce bio-fuels and biomaterials (Smith and Olesen, 2010).

Nevertheless, energy crops must not compete for land with food crops: this means that they must be cultivated in soils not useful for food crops, such as saline, polluted, and other marginal soils (Impagliazzo et al., 2017).

Climate change scenarios in the northern Mediterranean basin show a temperature increase, particularly in their summer peak values (Brunetti et al., 2000). Furthermore, cropland salinity is predicted to increase due to climate change (Yeo, 1998). This means that crops grown in the Mediterranean area, in the forthcoming years could be subjected to multiple stresses that are directly or indirectly related to greenhouse effects and climate changes.

A rise of 5-29 cm in the sea level is expected in the next 3040 years due to temperature increase, and its effects will be: waterlogging of coastal humid areas; fastest coastal erosion; intrusion of saline wedge into the estuary and into the river delta, and an increase of saline water infiltration into the groundwater of the coastal areas (Duce, 2005).

Salinity is one of the most important limiting factors for crop yield in many parts of the world; high saline concentration in soil solution $\left(>4 \mathrm{dS} \mathrm{m}^{-1}\right)$ reduce germination rate, growth and yield (Maas and Grattan, 1999). The first symptoms of saline stress are a growth decrease (Maas, 1986) and a reduction of leaf area index, followed by an increase in the specific leaf weight (leaf weight to leaf area ratio) (Longstreth and Nobel, 1979), a reduction in the number and dimension of the stomata (De Pascale et al., 1999), premature leaf senescence, and an overall yield decrease.

Greenway and Munns (1980) reported three different types of physiological stresses due to salinity: osmotic, nutritional, and toxic. The osmotic stress is due to the reduction of the soil water potential with a consequent reduction of root uptake, leaf water potential and stomatal conductance and, thus of photosynthetic rate. When salt stress becomes more intense, photosynthesis is 
limited also by the mesophyllic diffusive resistance and by metabolic damages (Cornic and Massacci, 1996; Flexas et al., 2004; Chaves et al., 2009). The nutritional stress depends mainly on the modification in the nutrient uptake due to $\mathrm{Na}^{+}$absorption (Munns and Termaat, 1986). Finally, the toxic stress depends on the accumulation of salts in the different organs of the plant, which, in turn, accelerates leaf senescence (Munns and Termaat, 1986). When the mortality rate of leaves overcomes the emission of new leaves, the whole-plant photosynthetic activity decreases.

All these adaptation mechanisms result in the yield decrease of glycophyte crops.

Among the different biomass crops for producing renewable energy aimed to reduce greenhouse gas emissions due to fossil fuels, giant reed (Arundo donax L.) is considered one of the most interesting species (Fagnano et al., 2015), thanks to its adaptability. It can grow in all soil textures, from heavy clay to sandy soils and it can withstand extended periods of severe drought (Lewandosky et al., 2003). Giant reed is native of Asia or of the Mediterranean basin, but it is now widely distributed in many temperate and sub-tropical areas of both hemispheres (Lewandosky et al., 2003).

Since it is a sterile plant, the natural variability may be due to spontaneous mutations and to natural selection as a response to different environmental conditions, and particularly to climatic stresses (Cosentino et al., 2006). It normally produces high lignocellulosic biomass yields in marginal lands, such as polluted soils (Fiorentino et al., 2010), hilly soil (Mantineo et al., 2009) also subjected to accelerated soil erosion (Fagnano et al., 2015), and under saline conditions (Williams et al., 2008; Williams et al., 2009). A. donax thanks to positive energy balance, due to high biomass production and low agro-management requirements (Lewandosky et al., 2003; Pompeiano et al., 2013), can became a promising crop for lignocellulosic feedstock (Pompeiano et al., 2017).

A. donax is a $\mathrm{C}_{3}$ species with particularly high assimilation and transpiration rates (Rossa et al., 1998; Webster et al., 2016) that are comparable to several $\mathrm{C}_{4}$ species. Presently, A. donax is not considered a halophyte because it primarily invades freshwater habitats (Nakley and Kim, 2015), but its salt tolerance has been proved worldwide: California, South Africa (Bell, 1997; Rossa et al., 1998), and Australia (Williams et al., 2008).

Recent studies report giant reed as moderately tolerant to salt stress (Nackley and Kim, 2015; Pompeiano et al., 2017), with an assimilation rate of $7-12 \mu \mathrm{mol} \mathrm{CO} \mathrm{Cm}^{-2} \mathrm{~s}^{-1}$ with $40 \mathrm{dS} \mathrm{m}^{-1}$ of water salinity.

This study aims to evaluate the adaptability of $A$. donax to increasing salinity levels in higher temperature conditions, from an agronomic and physiological point of view, in order to suppose a future use of this energy crop in marginal soils for salinisation in a perspective of climate changes.

\section{Materials and methods}

\section{Plant material, salt treatments and experimental design}

Rhizomes of giant reed were collected in March 2011 from a population growing in Bellizzi (SA), a coastal plain area of Southern Italy. The rhizomes were planted in $0.39 \mathrm{~m}^{2}$ pots, filled with $0.10 \mathrm{~m}$ of gravel for drainage, and $0.45 \mathrm{~m}$ of loamy sandy soil (ISSS classification; Table 1). The $70 \mathrm{~cm}$ diameter and $60 \mathrm{~cm}$ height pots (200 L volume) were allocated in the experimental field of the Department of Agriculture (40 $48.870^{\prime} \mathrm{N}$; $14^{\circ} 20.821^{\prime}$
E; $70 \mathrm{~m}$ a.s.1.) in Portici (Naples, Italy) under a $116 \mathrm{~m}^{2}(14.5 \times 8 \mathrm{~m})$ permanent metal structure, open on the sides and with a clear PE on the top, to avoid the interference of rainfall. The plants were irrigated during the growth cycle about once a week, with $370 \mathrm{~L}$ per pot corresponding to the decennial average rainfall $(950 \mathrm{~mm}$ per year).

Four levels of soil salinity [electrical conductivity (EC) 1:5 method] were initially imposed: control: EC soil between 0.2 and $0.6 \mathrm{dS} \mathrm{m}^{-1}$ (Control); low saline stress: EC soil between 0.6 and $1.0 \mathrm{dS} \mathrm{m}^{-1}$ (S1); medium-low saline stress: EC soil between 1.0 and $1.5 \mathrm{dS} \mathrm{m}^{-1}(\mathrm{~S} 2)$; moderate saline stress: EC soil between 1.5 and $2.0 \mathrm{dS} \mathrm{m}^{-1}(\mathrm{~S} 3)$. A completely randomised block design was adopted with 5 replicates per treatment.

The three levels of soil EC resulted from a precedent experiment on the response of food crops to salinity and they were obtained by saline irrigations at different salt concentrations (Mori et al., 2011). In order to maintain the initial soil salinity of the three treatments, every 15 days the soil EC was monitored by soil samplings in the layer $0-30 \mathrm{~cm}$. If the soil salt level was lower than that initially imposed, irrigation of saline treatments was carried out, adding tap water with common salt. The soil electrical conductivity (1:5 method) was measured with a conductimeter (Basic 30 CRISON), and the $\mathrm{pH}$ with a digital $\mathrm{pH}$ meter. Besides, the percentage of soil water content was determined with the gravimetric method.

ECe (saturated past) was calculated by using the following robust $\left(\mathrm{r}^{2}=0.98\right)$ equation, as proposed by Sonmez et al. (2008) for sandy soils:

$\mathrm{ECe}=8.22 \times \mathrm{EC}(1: 5)-0.33$

\section{Biometric and physiological measurements}

The measurements were carried out from April 2012 to January 2013 on re-sprouted plants after the first cut.

Plant growth was recorded nine times (every month), from 16 May 2012 to the harvest (early January 2013), by measuring the following parameters: number of stems, basal diameter, height of stems and number of green and yellow leaves.

At harvest, the fresh and dry weight of stems and leaves were measured. Dry matter values were determined after oven drying at $70^{\circ} \mathrm{C}$ until constant weight.

Measurements of all physiological parameters were taken on the uppermost sunlit well-expanded leaf in 5 replicate plants per treatment, with the exception of chlorophyll content index for which 12 leaves in each replicate plant were monitored (Table 1). Measurements were carried out between 10:00 am and 01:00 pm in the same days of the biometric samplings. Midday leaf water potential $\left(\Psi_{1}, \mathrm{MPa}\right)$ was measured by a Scholander pressure chamber (Model 3000; Soil Moisture Equipment Corp., Santa Barbara, CA, USA). Osmotic potential ( $\left.\Psi_{\mathrm{s}}, \mathrm{MPa}\right)$ measurements were carried on the same leaves used for gas-exchanges determination. The entire leaf lamina was frozen in liquid nitrogen and squeezed at fixed pressure to extract the cellular sap. The sap osmolality was measured by using a micro-osmometer (13/13 DR-AutocalHermann; Roebling Messtechnik, Berlin, Germany) and it was then converted into osmotic potential by using Morse's equation (Morse, 1914).

Net $\mathrm{CO}_{2}$ assimilation rate $\left(\mathrm{A}, \mu \mathrm{mol} \mathrm{m} \mathrm{m}^{-2} \mathrm{~s}^{-1}\right)$ at saturating light

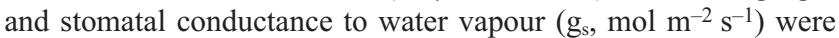
measured, by using a portable open-system gas-exchange analyser Li-6400 (Li-Cor Biosciences, Lincoln, NE, USA). Intrinsic water use efficiency $\left(\mathrm{WUE}_{\mathrm{i}}\right)$ was calculated as the ratio $\mathrm{A} / \mathrm{gs}\left(\mu \mathrm{mol} \mathrm{mol}{ }^{-1}\right)$. The $\mathrm{CO}_{2}$ inside leaf chamber was supplied by an external cartridge 
to obtain a flow rate of $400 \mu \mathrm{mol} \mathrm{mol}{ }^{-1}$ air. A LED light source, with emission peaks centred at $670 \mathrm{~nm}$ in the red and at $465 \mathrm{~nm}$ in the blue, provided a photosynthetic photon flux density (PPFD) equal to $2000 \mu \mathrm{mol} \mathrm{m} \mathrm{m}^{-1}$ (90\% red, $10 \%$ blue). The software of the instrument (Li-Cor, 2011) calculated the gas-exchange parameters based on the von Caemmerer and Farquhar (1981) model.

Chlorophyll $a$ fluorescence was measured, by using a continuous excitation Handy PEA fluorimeter (Hansatech Instruments Ltd., King's Lynn, Norfolk, UK). Fluorescence was induced by a red $(650 \mathrm{~nm})$ light diode source for $1 \mathrm{~s}$ at the maximal available PPFD of $3500 \mu \mathrm{mol} \mathrm{m} \mathrm{m}^{-2} \mathrm{~s}^{-1}$ (Strasser et al., 2000; Giorio et al., 2011). The leaves were dark adapted for $30 \mathrm{~min}$ by means of the equipped white leaf-clips, prior to the determination of maximum quantum yield of PSII photochemistry calculated by the instrument software as $\mathrm{F}_{\mathrm{V}} / \mathrm{F}_{\mathrm{m}}=\left(\mathrm{F}_{\mathrm{m}}-\mathrm{F}_{\mathrm{O}}\right) / \mathrm{Fm}_{\mathrm{m}}$, according to Kitajima and Butler (1975).

The chlorophyll content was assessed as an optical index by using a handheld meter CCM-200 plus (Apogee Instruments, Inc., Logan, UT, USA). The meter measures the ratio between the leaf transmittance at 653 and $931 \mathrm{~nm}$ and calculates the chlorophyll content index, which is proportional to the amount of chlorophyll in the leaf.

\section{Statistical analysis}

The experimental design was one factor randomised complete block design combined over years (dates) with soil salinity as main factor and dates as repeated measures over the time.

The biometric data were analysed with MSTAT software (Crop and Soil Science Department, Michigan State University, Version 2.0). Physiological variables were processed by one-way ANOVA, followed by Tukey's multiple comparisons test, using GraphPad Prism version 6.00 (GraphPad Software, La Jolla, California, USA).

\section{Results}

\section{Air temperature}

The trend of minimum and maximum air temperature during the crop cycle is shown in Figure 1. The temperature was higher under the shelter than outside, especially in the summer months, when the difference was $14.5^{\circ} \mathrm{C}$ for $\mathrm{T}_{\max }$ and $3.2^{\circ} \mathrm{C}$ for $\mathrm{T}_{\min }$.

\section{Soil moisture and salinity}

The soil EC varied during the cycle; however, across the average, they were within the range imposed (Table 2). The soil water content (average of all samplings) increased as soil salinity increased (Table 2).

\section{Plant growth}

The main effects of soil salinity and sampling date were significant for all the growth parameters (Table 3). Interactions were not significant.

The effects of the two factors are reported in Table 4. The stem number per pot increased until the begin of August, although since July there were no significant differences (Table 4). The salt stress caused a significant decrease of stems emission (Table 4): the stem number of the most stressed treatment was about $45 \%$ lower than the control, but it was not different from the S2 treatment.

The increase in the stem height lasted until the beginning of
Table 1. Physical and chemical proprieties of soil.

\begin{tabular}{lcc}
\hline Texture & & \\
- Coarse sand & $\%$ & 47.0 \\
- Fine sand & $\%$ & 36.6 \\
\hline - Silt & $\%$ & 11.9 \\
- Clay & $\%$ & 4.5 \\
\hline $\mathrm{N}$ - total (Kjeldahl method) & $\mathrm{g} \mathrm{kg}^{-1}$ & 0.45 \\
$\mathrm{P}_{2} \mathrm{O}_{5}$ (Olsen method) & $\mathrm{ppm}$ & 117.1 \\
\hline $\mathrm{K}_{2} \mathrm{O}$ (Tetraphenylborate method) & $\mathrm{ppm}$ & 245.4 \\
Organic matter (Bichromate method) & $\%$ & 0.90 \\
\hline Bulk density & $\mathrm{kg} \mathrm{dm}^{-3}$ & 1.32 \\
\hline
\end{tabular}

Table 2. Average values of electrical conductivity, measured with 1:5 method and estimated saturated paste method (Sonmez et al., 2008) and average values of percentage soil water content (gravimetric method) for all treatments. The values are the average of all pots per each treatment during all cycle.

\begin{tabular}{lccc} 
Treatment & \multicolumn{2}{c}{ EC $\left(\mathrm{dS} \mathrm{m^{-1 } )}\right.$} & SWC (\%) \\
& $1: 5$ & Saturated paste & \\
Control & 0.44 & 3.29 & 9.9 \\
S1 & 0.99 & 7.81 & 10.3 \\
\hline S2 & 1.40 & 11.18 & 11.9 \\
S3 & 1.93 & 15.53 & 13.4 \\
\hline
\end{tabular}

EC, electrical conductivity; SWC, soil water content.

Table 3. Analysis of variance on biometric parameters: significance of main factors. LSD indicates least minimum difference.

\begin{tabular}{lcccc} 
Parameter & \multicolumn{4}{c}{$\begin{array}{c}\text { Main factors } \\
\text { Soll salinity }\end{array}$} \\
& Significance LSD & Significance & LSD \\
Stem number & 0.01 & 0.78 & 0.01 & 1.78 \\
Stem height & 0.01 & 8.50 & 0.01 & 9.03 \\
\hline Green leaves number & 0.01 & 7.64 & 0.01 & 18.00 \\
Yellow leaves number & 0.01 & 4.23 & 0.01 & 10.27 \\
\hline
\end{tabular}

Table 4. Main effect of soil salinity and sampling date on number and height of stem and number of green and yellow leaves (when present).

\begin{tabular}{|c|c|c|c|c|}
\hline \multirow[t]{2}{*}{ Treatment } & \multicolumn{2}{|c|}{ Stem } & \multirow{2}{*}{$\begin{array}{c}\text { Green } \\
\text { leaves } \\
\text { No. }\end{array}$} & \multirow{2}{*}{$\begin{array}{c}\text { Yellow } \\
\text { leaves } \\
\text { No. }\end{array}$} \\
\hline & No. & $\begin{array}{l}\text { Height } \\
\text { (cm) }\end{array}$ & & \\
\hline \multicolumn{5}{|l|}{ Sampling date } \\
\hline 16-May & $4.62^{\mathrm{c}}$ & $23.16^{\mathrm{f}}$ & $31.31^{\mathrm{d}}$ & - \\
\hline 13-June & $5.68^{\mathrm{bc}}$ & $50.09 \mathrm{e}$ & $54.88^{c}$ & - \\
\hline 11-July & $7.06^{\mathrm{ab}}$ & $87.48^{d}$ & $81.69^{b}$ & $8.37^{\mathrm{d}}$ \\
\hline 06-August & $7.50^{\mathrm{a}}$ & $122.64^{\mathrm{c}}$ & $101.81^{\mathrm{a}}$ & $15.18^{\mathrm{c}}$ \\
\hline 05-September & $7.62^{\mathrm{a}}$ & $148.09^{b}$ & $109.31^{\mathrm{a}}$ & $20.94^{c}$ \\
\hline 03-October & $7.62^{\mathrm{a}}$ & $166.35^{\mathrm{a}}$ & $113.68^{\mathrm{a}}$ & $32.68^{b}$ \\
\hline 31-October & $7.69^{a}$ & $169.47^{\mathrm{a}}$ & $105.88^{\mathrm{a}}$ & $48.06^{\mathrm{a}}$ \\
\hline 29-November & $7.69^{\mathrm{a}}$ & $171.36^{\mathrm{a}}$ & $81.25^{b}$ & $53.94^{\mathrm{a}}$ \\
\hline \multicolumn{5}{|l|}{ Soil salinity } \\
\hline Control & $9.06^{\mathrm{a}}$ & $119.76^{\mathrm{b}}$ & $103.66^{\mathrm{a}}$ & $31.03^{\mathrm{a}}$ \\
\hline S1 & $7.84^{\mathrm{b}}$ & $133.25^{\mathrm{a}}$ & $95.78^{b}$ & $25.72^{\mathrm{a}}$ \\
\hline S2 & $5.78^{\mathrm{c}}$ & $126.04^{\mathrm{ab}}$ & $81.31^{\mathrm{c}}$ & $15.81^{b}$ \\
\hline S3 & $5.06^{\mathrm{c}}$ & $92.28^{c}$ & $59.16^{\mathrm{d}}$ & $17.03^{b}$ \\
\hline
\end{tabular}

a-f Values with different letters indicate significant differences at $(\mathrm{P} \leq 0.01)$. 
October (Table 4); in the two successive samplings, there were no further increases.

The effect of saline stress on the stem height was not very strong; only the S3 plants were statistically shorter than the all other treatments. The rate of stem elongation had a parabolic trend for all treatments (Figure 2); however, each reached the maximum peak in a different moment of season and with different values. The elongation of stems of the control plants began earlier than the other treatments with the highest rate (cm per day) until June, while the three saline treatments showed the higher stem elongation rates in the summer months.

During the cycle, the number of green leaves had a parabolic trend; the control reached the maximum in September, and the saline treatments in October; starting from the end of October, the green leaves number began to decrease significantly (Figure 3). The effect of saline stress on the green leaf number was very strong: the most stressed treatment showed the half of the green leaves of control (Table 4).

The first yellow leaves were recorded in July, and their number significantly increased until the harvest (Table 4). The yellow leaves decreased as the soil salinity increased, but only in S2 and S3 treatments they were different from the control (Table 4). The sum of the green and yellow leaves was significantly lower in the two most stressed treatments, about $28 \%$ and $43 \%$ less than the control.

The percentage of the number of green and yellow leaves on the total number of leaves (Figure 4), in the four most important moments of cycle (beginning, first emission of yellow leaves, full activity of plants, and end cycle/senescence), confirms that the control plants had a faster cycle; in fact, the senescence began earlier in control plants, and only at the end of October the percentage of yellow leaves of S3 plants was comparable with the control.

\section{Physiological responses}

Leaf water potential $\left(\Psi_{1}\right)$ in May did not show significant differences among all the treatments, with an overall mean of -1.71 $\mathrm{MPa}$ (Figure 5A). Afterwards, $\Psi_{1}$ was higher in the control than in the saline treatments, with a $0.70 \mathrm{MPa}$ difference between control and S3 in July and August.

The osmotic potential of the leaf sap (Figure 5B) was not affected by salinity from June to August, showing an average of $1.63 \mathrm{MPa}$ in all treatments. In October, it was $0.48 \mathrm{MPa}$ lower in $\mathrm{S} 3$ than in the control plants $(-1.93 v s-1.45 \mathrm{MPa})$.

During the whole experiment, the stomatal conductance in S1, $\mathrm{S} 2$, and S3, was significantly lower than the control plants, with the exception of S1 in June (Figure 6A). However, no significant differences were found among the saline treatments. As an average of the three saline treatments, $g_{s}$ progressively decreased from 0.20 in June, to 0.045 in July, and $0.021 \mathrm{~mol} \mathrm{~m}^{-2} \mathrm{~s}^{-1}$ in August; the latter two corresponding to $10 \%$ and $13 \%$ of the control, respectively.

The assimilation rate (A) broadly followed the $\mathrm{g}_{\mathrm{s}}$ pattern (Figure 6B). The three salt treatments showed average values of $5.3 \mu \mathrm{mol} \mathrm{m} \mathrm{m}^{-2} \mathrm{~s}^{-1}$ in July and 6.7 in August, corresponding to $21 \%$ and $32 \%$ of the control, respectively. The two gas exchange parameters, partially recovered in October and November, when the data were comparable with those recorded in May.

Intrinsic water use efficiency remained almost stable until July, ranging from 86 to $123 \mu \mathrm{mol} \mathrm{mol}^{-1}$ in all treatments (Figure $6 \mathrm{C}$ ). As expected, a noticeable increase was observed in August under the most stressful conditions, when $\mathrm{A} / \mathrm{g}_{\mathrm{s}}$ was 2.5 -fold higher in $\mathrm{S} 1$ and S2, and 3.9-fold in S3 as compared to the control. Afterward, $\mathrm{A} / \mathrm{g}_{\mathrm{s}}$ values progressively decreased in November as compared with those recorded in May.

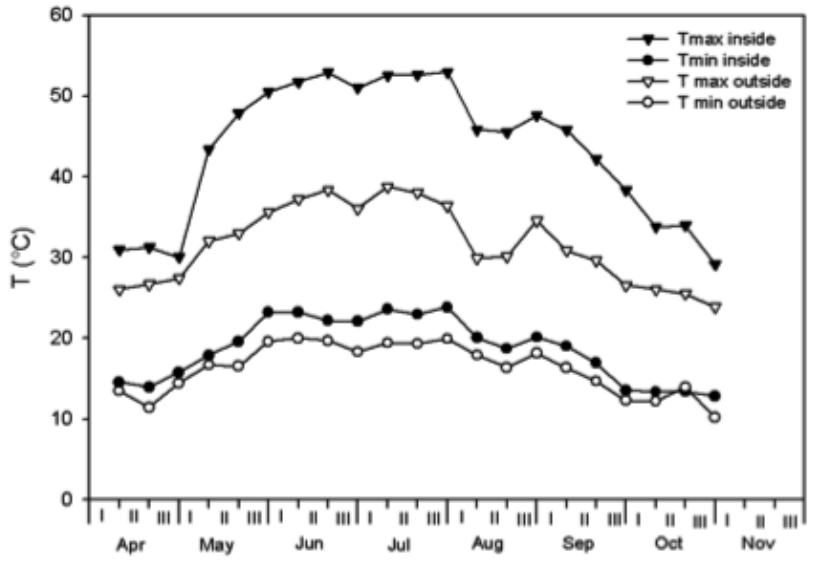

Figure 1. Trend of maximum and minimum temperatures under and out the shelter during the experiment.

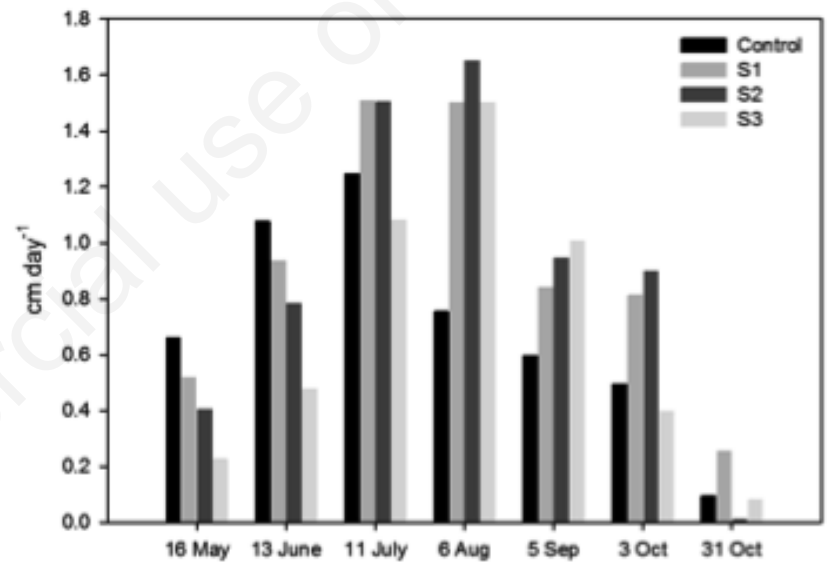

Figure 2. Increase of stems height $\left(\mathrm{cm} \mathrm{day}^{-1}\right)$ of the four treatments during the cycle.

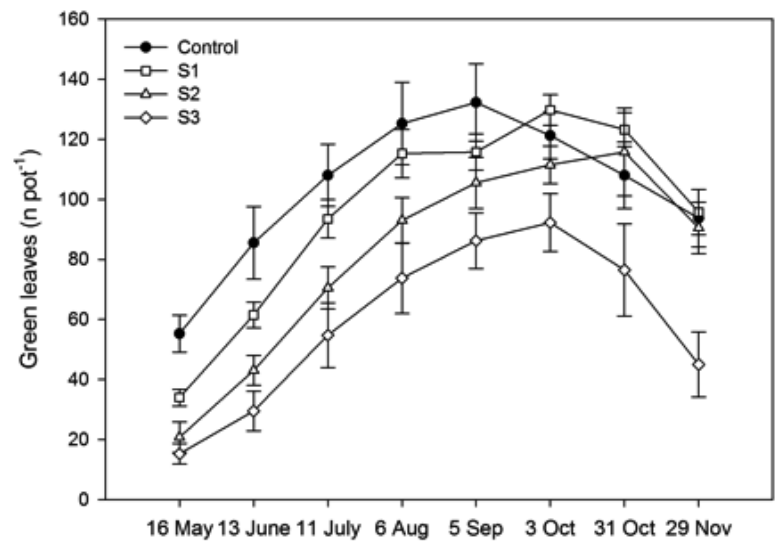

Figure 3. Trend of green leaves number during the experiment. The vertical bars are standard errors. 
The Fv/Fm ratio remained stable around an overall mean of 0.77 (r.u.) throughout the whole experiment, with no significant differences between the control plants and those subjected to salt treatment (S1, S2, S3) (Figure 6D).

The chlorophyll content index, measured over a few dates, resulted as anerage $22 \%$ lower in the control than in the saline treatments (Figure 7).

\section{Biomass yield}

The yield and related parameters were all significantly affected by the soil salinity (Table 5 ).

The biomass yield (fresh weight) of the two less stressed treatments (S1 and S2) were not significantly different from the control; the S3 yield was about the half of the average value of the other three treatments (Table 6).

S1 and S2 plants showed a higher average weight of stems and a lower emission capacity of stems than the control but the differences were not significant.

The S3 plants always showed the lowest values for all parameters of yield (Table 6). In addition, the percentage of dry matter was higher for the control and the two less-stressed treatments (51.5 vs 49.1\%, average of values of control, S1 and S2 and value of S3 respectively).

Yield was strongly correlated with soil salinity $\left(\mathrm{r}^{2}=0.99\right)$ (Figure 8 ); the model estimates $100 \%$ yield loss at EC of $2.3 \mathrm{dS} \mathrm{m}^{-1}$ (1:5 method), corresponding to the ECe of $18.6 \mathrm{dS} \mathrm{m}^{-1}$.

Similarly, the tolerance of the giant reed to salinity was also confirmed by applying Maas and Hoffman equation (1977). In fact, we found that the tolerance threshold to salinity (value beyond which the yield loss begins) for A. donax is $11.2 \mathrm{dS} \mathrm{m}^{-1}$ and the relative growth decrease was $11.6 \%$ per $1 \mathrm{dS} \mathrm{m}^{-1}$ increase. The percentage incidence of leaves dry matter increased with

Table 5. Analysis of variance on yield parameters at harvest: significance of main factors.

\begin{tabular}{|c|c|c|}
\hline \multirow[t]{2}{*}{ Parameter } & \multicolumn{2}{|c|}{ Soil salinity } \\
\hline & Significance & LSD \\
\hline Stem number per pot & 0.05 & 3.06 \\
\hline Stem basal diameter & 0.01 & 0.14 \\
\hline Stem height & 0.05 & 43.47 \\
\hline Stem average weight & 0.05 & 7.71 \\
\hline Yield ( $\mathrm{kg} \mathrm{m}^{-2}$ fresh weight) & 0.05 & 0.45 \\
\hline
\end{tabular}

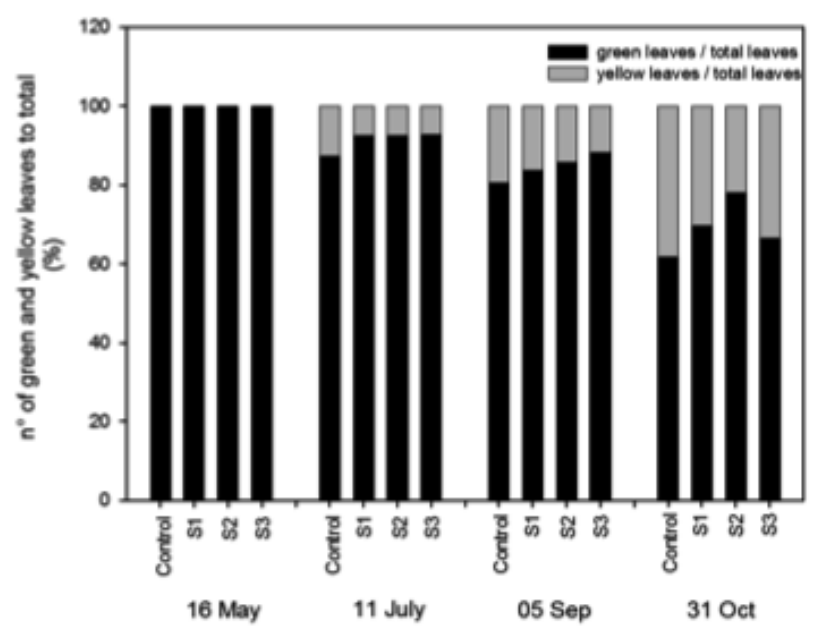

Figure 4. Percentage incidence of number of green and yellow leaves to total number of leaves in four most significant sampling dates.

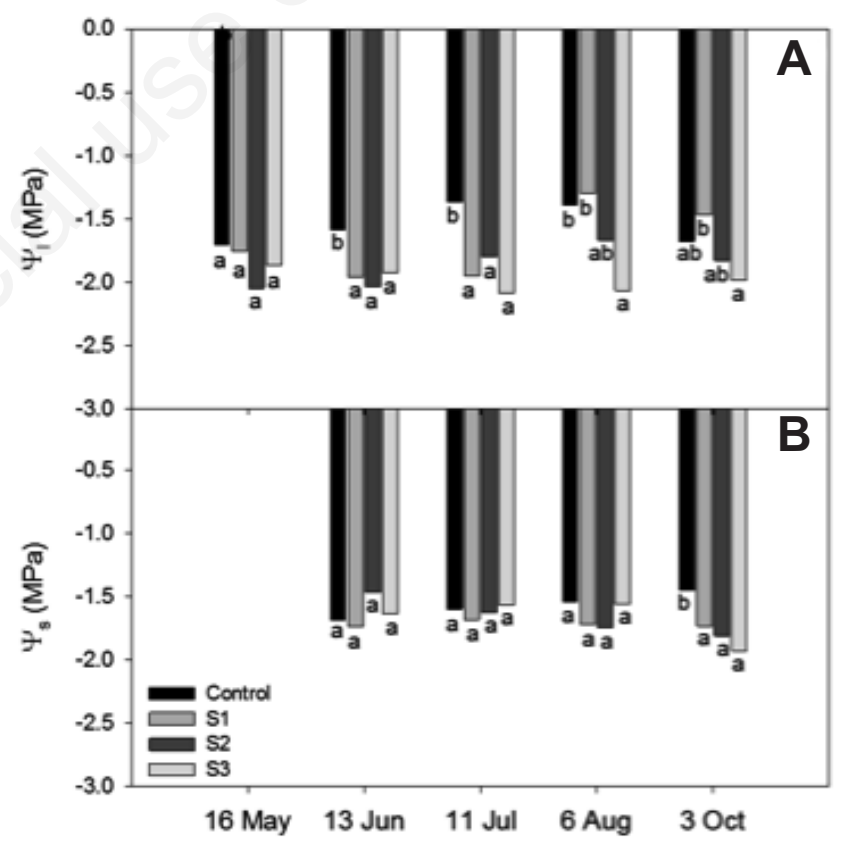

Figure 5. Leaf water potential (A) and osmotic potential (B). Values represent average measurements, $n=5$. Bars with the same letter are not significantly different according to Tukey test $(\mathbf{P}<0.05)$.

Table 6. Effect of soil salinity on yield (fresh weight) and its parameters at harvest.

\begin{tabular}{|c|c|c|c|c|c|c|}
\hline Treatment & $\begin{array}{c}\text { Number } \\
\text { (No.) }\end{array}$ & $\begin{array}{l}\text { Height } \\
\text { (cm) }\end{array}$ & $\begin{array}{l}\text { Diameter } \\
\text { (cm) }\end{array}$ & $\begin{array}{l}\text { Average weight } \\
(\text { g stem }\end{array}$ & $\begin{array}{l}\text { Yield } \\
\text { Fresh weight } \\
\left(\mathrm{kg} \mathrm{m} \mathrm{m}^{-2}\right)\end{array}$ & $\begin{array}{l}\text { Dry matter } \\
(\%)\end{array}$ \\
\hline Control & $9.5^{\mathrm{a}}$ & $158.2^{a b}$ & $1.11^{\mathrm{a}}$ & $39.0^{\mathrm{b}}$ & $1.14^{\mathrm{a}}$ & 52.0 \\
\hline S1 & $8.5^{\mathrm{a}}$ & $192.1^{\mathrm{a}}$ & $1.08^{a}$ & $51.3^{\mathrm{a}}$ & $1.43^{\mathrm{a}}$ & 52.5 \\
\hline S2 & $6.8^{\mathrm{ab}}$ & $188.8^{a}$ & $0.98^{\mathrm{a}}$ & $54.1^{\mathrm{a}}$ & $1.22^{\mathrm{a}}$ & 50.1 \\
\hline S3 & $5.3^{b}$ & $137.5^{\mathrm{b}}$ & $0.77^{\mathrm{b}}$ & $35.2^{\mathrm{b}}$ & $0.64^{b}$ & 49.1 \\
\hline
\end{tabular}

${ }^{a-b}$ Values with different letters indicate significant differences at $P \leq 0.05$ and only for stem basal diameter at $P \leq 0.01$. 
saline stress, in fact the two more stressed treatments was slightly higher than the other two ones, $30.1 \%$ vs $23.0 \%$ respectively (Figure 9).

\section{Discussion and conclusions}

The salt tolerance of a crop depends not only on the intensity of saline stress but also on genotype, other biotic or abiotic stress (temperature, water deficit, soil physical conditions) and crop

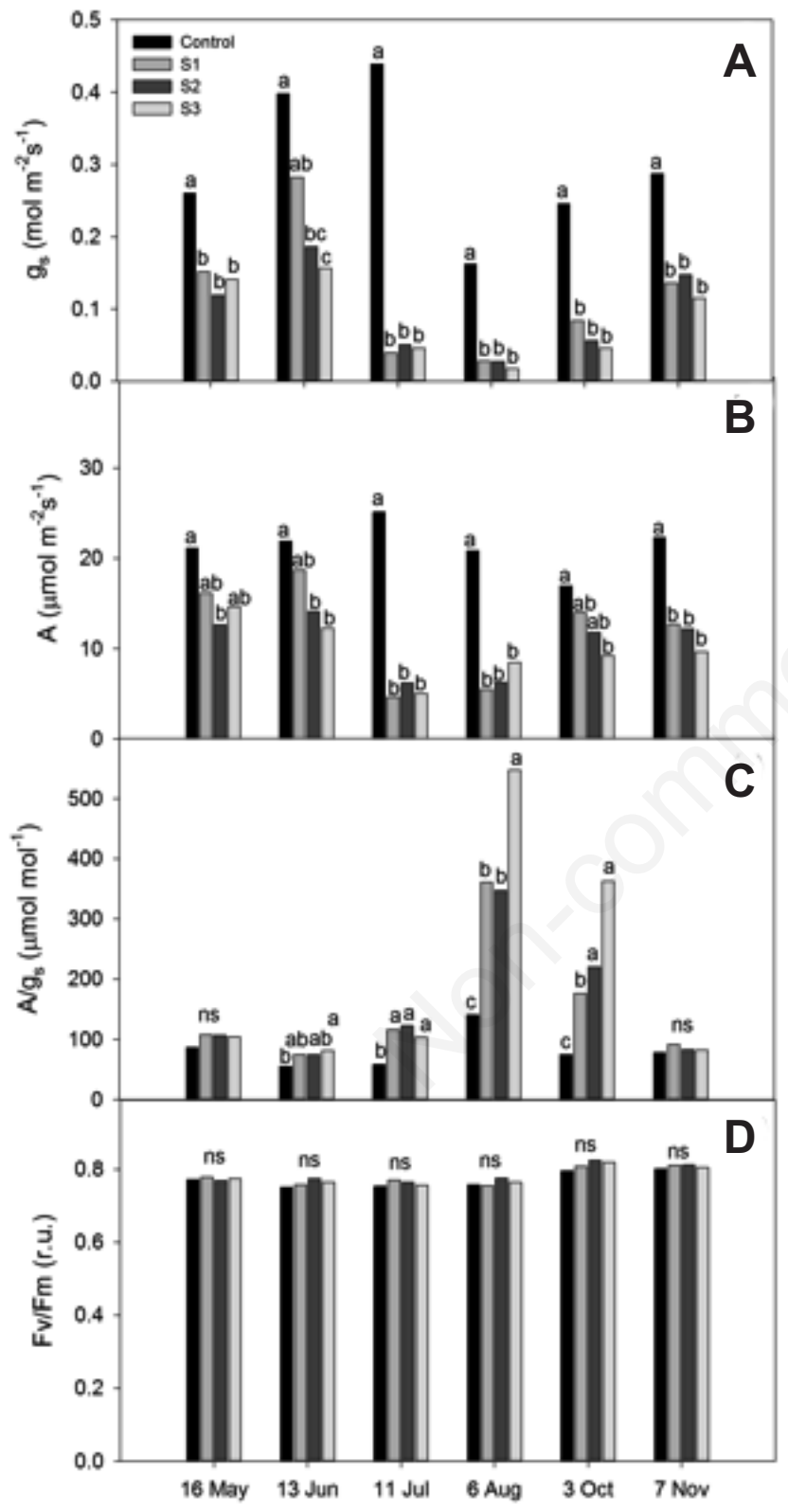

Figure 6. Stomatal conductance to water vapour (A), net $\mathrm{CO}_{2}$ assimilation $(B)$, intrinsic water use efficiency $(C)$ and maximum quantum yield of PSII (D). Values represent average measurements, $n=5$ for $A$ ), B), C) and $n=20$ for D). Bars with the same letter are not significantly different according to Tukey test $(\mathbf{P}<0.05)$. practices (Läuchli and Epstein, 1990). Many studies were carried out about the effect of salt on growth, physiology and yield of several food crops: tomato (Mori et al., 2008); potato (Patel et al., 2001); bean (Bayuelo-Jimenez et al., 2003); snap bean (Mori et al., 2011); cauliflower and broccoli (De Pascale et al., 2005), while,

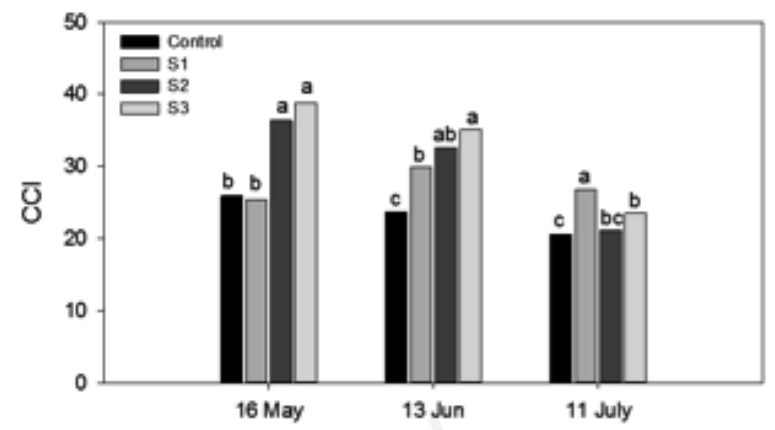

Figure 7. Content of chlorophyll $a$. Values represent average measurements, $n=20$. Bars with the same letter are not significantly different according to Tukey test $(\mathbf{P}<0.05)$.

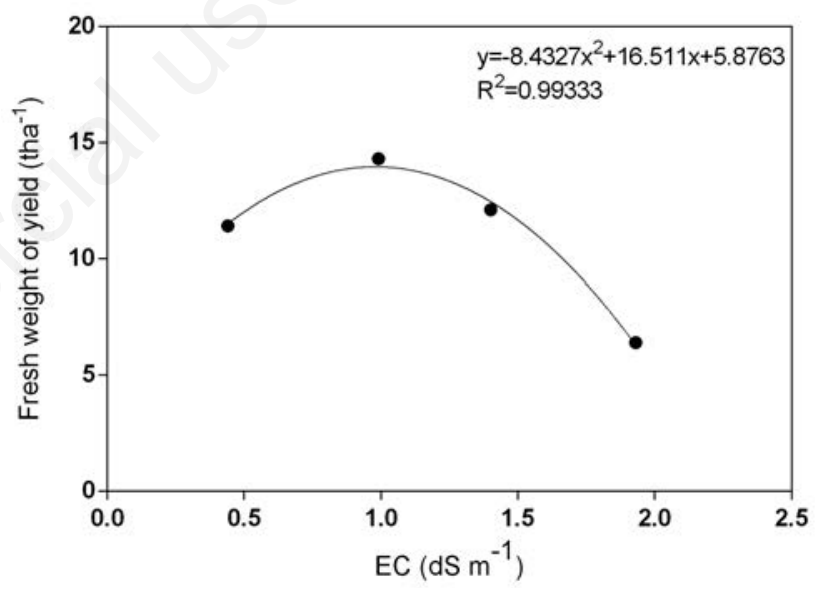

Figure 8. Yield (t ha $\mathrm{h}^{-1}$ F.W.) $v s$ average electrical conductivity of soil. The line represents the best fit regression model.

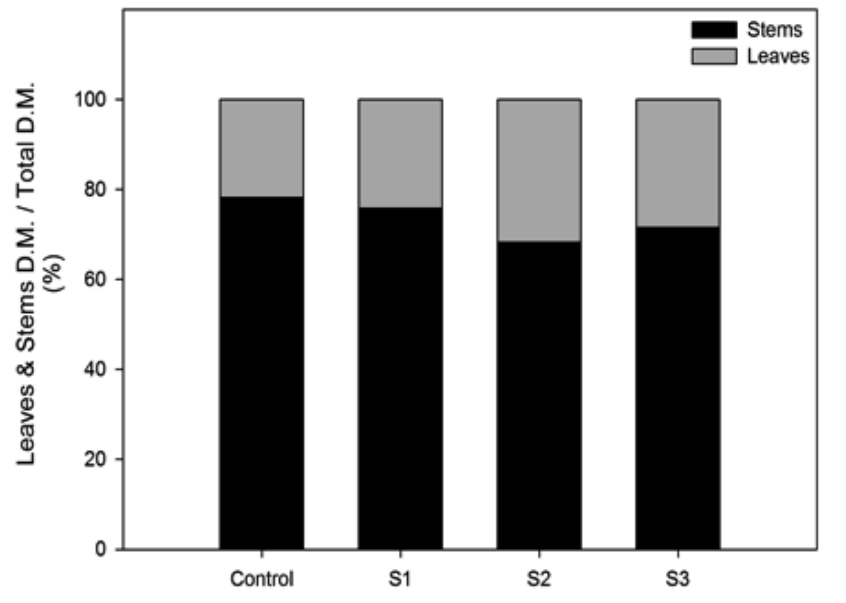

Figure 9. Percentage incidence of stems and leaves dry matter on total dry matter of plants of four treatments. 
few studies were carried out on biomass crops. To get complete information about the response of a crop to salinity, it is necessary to evaluate the behavior of plants at different times of the cycle in which the salt stress occurs. Therefore, it is important to evaluate: i) the survival of plants (sowed or transplanted) on saline soil; ii) the plant growth (absolute or relative, as compared to no-saline condition); and iii) the yield reduction. About the first point, our results confirmed that $A$. donax is able to survive on saline soil; in fact, the rhizomes of all treatments sprouted, in agreement with results reported by Nackely and Kim (2015) for stem cuttings of $A$. donax.

However, as it is well-known about food crops (Shahbaz et al., 2012), likewise for giant reed, the early growth phases are the more sensitive; in fact, sprouting capacity of rhizomes reduces to increasing saline stress (the stem number of the most stressed treatments was almost the half of control), as also reported by Sanchez et al. (2015).

The stem height decreased with saline stress; probably this parameter was also negatively influenced by the number of stems, according to Angelini et al. (2009); we found a relation between the number of stems per pot and their height $\left(\mathrm{y}=2.7982 \mathrm{x}^{3}-\right.$ $\left.67.924 x^{2}+536.4 x-1245.5 ; R^{2}=0.999\right)$. This equation individuates, in our experimental conditions, an optimal range of stems per square meter, that ranged from 15 to 20 , and that allowed the maximum elongation of stems. If the number of stems per pot is higher than 8 , like it was for control plants, the height of stems is reduced, probably due to the higher competition for space and/or nutrients, reaching height values similar to those of the plants of most stressed treatments. On the other hand, as also found by Sanchez et al. (2015), the stem height decreased in the saline and saline-water stressed treatments. These researchers also found a decrease in stem diameter that ranged from $0.7 \mathrm{~cm}$ in control plants (wellwatered with no-saline solution) to $0.6 \mathrm{~cm}$ in the most stressed plants (low watered with saline solution). We also found a similar effect of saline stress, but our values of basal diameter of stems was higher and, at harvest, ranged from $1.1 \mathrm{~cm}$ of control plants to $0.77 \mathrm{~cm}$ of S3 plants.

Additionally, the growth rate of plants was affected by salt stress in particular, which is especially evident for stem elongation rate. In fact, the control plants already showed a maximum elongation of stems in the first months of cycle, according to Spencer et al. (2005), which found that growth (stem elongation, leaf production and RGR) was most rapid prior to the second week in June, and to Nassi o Di Nasso et al. (2011) which highlighted the maximum crop growth rate at the middle of June. On the other hand, Triana et al. (2014) identified four growth stage for Arundo donax: i) initial (crop sprouting-beginning of stem elongation); ii) crop development, corresponding to stem elongation; iii) mid-season (end of stem elongation-beginning of canopy senescence); iv) late season (canopy senescence-end of water uptake), and in both test years the phase of elongation stem started about at beginning-middle of May and ended at most at 12 June, according to our findings about the control plants.

Probably the elongation activity for the stressed plants started later because the plants grown under salt stress needed a period of adjustment to saline conditions before starting to develop, and this period seems to be longer with greater salt concentration, as already indicated by the rhizomes sprouting capacity.

This hypothesis (the necessity of a period of adjustment) seems to be confirmed by the observation that from July the rate of elongation stems of these plants was even higher than the elongation rate of control plants. It is possible that in the first months of the cycle, these plants mainly used their energy to activate the mecha- nisms of adaptation to salt stress and/or develop roots, as already reported as a response of these crops to other environmental stresses (Fiorentino et al., 2017). In addition, the early emission of the yellow leaves of the control plants, seems to indicate that the cycle of these plants was faster, as confirmed at the harvest also by a higher dry matter percentage than the two more stressed treatments. However, the plants grown in saline conditions recovered from the delay, except for the most stressed plants that were the only ones to reduce biomass yield.

Similarly to the results reported by Sanchez et al. (2015), for the total dry weight of plants watered with saline solution of $16 \mathrm{dS}$ $\mathrm{m}^{-1}$, we also observed a negative relationship between the aboveground biomass per plant and salinity, but only in the most stressed treatments.

The physiological performances of potted giant reed in the control treatment were comparable with those reported in other experiments made with plants grown either in pots or in open field conditions: the mean seasonal stomatal conductance $\left(0.298 \mathrm{~mol} \mathrm{~m}^{-2} \mathrm{~s}^{-1}\right)$ and assimilation rates $\left(21.4 \mu \mathrm{mol} \mathrm{m} \mathrm{m}^{-2} \mathrm{~s}^{-1}\right)$ in control plants were similar to those reported by Sanchez et al. (2015) in potted plants grown in greenhouse, by Cosentino et al. (2016) in two-year old fully irrigated plants in open field conditions, and by Webster et al. (2016) in natural stands. We are not aware of research reporting leaf water potential of giant reed under salt stress conditions; however, Cosentino et al. (2016), in plant irrigated with 50\% ETM, and Mann et al. (2013), under mild drought (9\% soil moisture, soil matric potential, $\left.\Psi_{\mathrm{m}}=-0.5 \mathrm{MPa}\right)$, reported leaf water potential values proximal to the values $(-2.08 \mathrm{MPa})$ measured in our S3 treatment. Therefore, we can infer that the most salt-stressed plants of our experiment experienced mild stress conditions. Under open field conditions during the summer, a decrease of $g_{s}$ in control plants as a mechanism of drought avoidance (Jones, 1992) is normally observed, because of the increased atmospheric evaporative demand. In our experiment, plants grown under the shelter, experienced higher VPD (data not shown) and temperature (Figure 1) than in open air, which induced an evident $g_{s}$ reduction in early August. The interaction between such environmental conditions and salinity can explain the marked decrease of stomatal conductance. We observed a good relationship between $\mathrm{A}$ and $\mathrm{g}_{\mathrm{s}}$ (data not shown) in all treatments as reported by Nackley and Kim (2015) on the same species. This would indicate that the reduction of assimilation rate could be ascribed to a lower availability of $\mathrm{CO}_{2}$ due to stomatal closure. Moreover, same Authors reported that plants irrigated with saline water $\left(40 \mathrm{dS} \mathrm{m}^{-1}\right)$ reached stomatal conductance of about $0.05 \mathrm{~mol} \mathrm{~m}^{-2} \mathrm{~s}^{-1}$ without impairment of PSII photochemistry, as showed by high $\phi_{\text {PSII }}$ values. We found high values of $F_{v} / F_{m}$ in all treatments during the entire experiment, indicating that, under our experimental conditions, PSII reaction-centres were not compromised (Baker, 2008). Indirect evidence that photosynthetic limitation was only due to stomata and not due to photosynthetic machinery can also be deduced by the strong increase in intrinsic WUE at low g (Cifre et al., 2005; Flexas et al., 2005), as observed under the most stressful conditions in summer.

Salt stress causes a reduction in the chlorophyll content as found in rice (Ali et al., 2004) and pearl millet (Sneha et al., 2014). As regards Arundo donax, Nackley et al. (2015) found no variation in plants irrigated with saline water (ECw 0-40 $\mathrm{dS} \mathrm{m}^{-1}$ ), while Sanchez et al. (2015) observed either an increase or no variation in moderately salt stressed plants, depending on genotypes, as we found in our experiment. It can be speculated that shrinkage or reduced expansion of leaves in stress treatments may have contributed to enhance the leaf specific chlorophyll content (Tang and Boyer, 2007). Both gas-exchange and fluorescence parameters 
indicate the stability of photosynthesis in A. donax under mild salinity conditions. Arundo donax L. has been identified as a promising bioenergy crop that may be able to maintain high growth rates with little resource supplements (Lewandoski et al., 2003) producing large amounts of biomass, both above and below ground (Sharma et al., 1998).

In fact, despite $A$. donax was cultivated in pots and sited in shelter where summer temperatures exceeded $50^{\circ} \mathrm{C}$, the average yield (second year of cultivation) of control and the S1 and S2 treatments was $6.5 \mathrm{t} \mathrm{ha}^{-1}$ (dry weight with $51.5 \%$ average dry matter), and it was higher than that found by Fagnano et al. (2015) in the first year of cultivation of giant reed in marginal environment (hill) and approximately $65 \%$ of yield of the second year. The high value of dry matter percentage $(51.5 \%$ vs $48.1 \%$ reported by Fagnano et al., 2015, as average of nine harvests) allows minimising the risks of fermentation during the post-harvest storage. Additionally, the percentage of leaves on total dry matter of plants of control and S1 treatments $(23.0 \%)$ is similar to that reported by Fagnano et al. (2015) (19.9\%, as average of nine harvests in a hilly area).Therefore $A$. donax can be considered as moderately sensitive to salinity, according to Nakley and Kim (2015).

A. donax, also grown in higher temperature, resulted suitable to saline soil conditions with a decrease of only $50 \%$ of yield at a salinity level of $15.5 \mathrm{dS} \mathrm{m}^{-1}$.

In addition, the parameters of yield (height, basal diameter, and average stem weight) are negatively influenced, only by the strongest conditions of soil salinity.

The saline stress affects the length of the biological cycle of giant reed, probably due to the plant need of an initial period of adaptation to saline conditions; in fact, the percentage incidence of leaves at harvest also increases with increasing saline stress.

The saline stress reduced the stomatal conductance and assimilation rate, probably also due to an interaction with the high summer temperatures registered under the shelter, while the photosynthetic machinery was not affected.

Therefore, by this preliminary experiment, giant reed proves to be suitable to marginal lands, such as saline soils, where it can produce a good biomass feedstock thus offering a valid alternative to the abandonment of these areas that are unsuitable for growing food crops, also in a perspective of higher temperatures.

\section{References}

Ali Y, Aslam Z, Ashraf MY, Tahir GR, 2004. Effect of salinity on chlorophyll concentration, leaf area, yield and yield components of rice genotypes grown under saline environment. Int. J. Environ. Sci. Te. 1:221-5.

Angelini LG, Ceccarini L, Nassi o Di Nasso N, Bonari E, 2009. Comparison of Arundo donax L. and Miscanthus x giganteus in a long-term field experiment in Central Italy: Analysis of productive characteristics and energy balance. Biomass Bioener. 33:635-43.

Baker NR, 2008. Chlorophyll fluorescence: a probe of photosynthesis in vivo. Annu. Rev. Plant Biol. 59:89-113.

Bayuelo-Jimenez JS, Debouck DG, Lynch JP, 2003. Growth, gas exchange, water relations, and ion composition of Phaseolus species grown under saline conditions. Field Crop. Res. 80:207-22.

Bell GP, 1997. Ecology and management of Arundo donax L. and approaches to Riparian Habitat restoration in Southern California. In: J. Brock (Ed.), Plant invasions: studies from
North America and Europe. Backhuys, Leiden, The Netherlands, pp 103-113.

Brunetti M, Maugeri M, Monti F, Nanni T, 2006. Temperature and precipitation variability in Italy in the last two centuries from homogenised instrumental time series. Int. J. Climatol. 26:345-81.

Chaves MM, Flexas J, Pinheiro C, 2009. Photosynthesis under drought and salt stress: regulation mechanisms from whole plant to cell. Ann. Bot. 103:551-60.

Cifre J, Bota J, Escalona JM, Medrano H, Flexas J, 2005. Physiological tools for irrigation scheduling in grapevine (Vitis vinifera L.): An open gate to improve water-use efficiency? Agric. Ecosys. Environ. 106:159-70.

Cornic G, Massacci A, 1996. Leaf photosynthesis under drought stress. In: N.R. Baker (Ed.) Photosynthesis and the Environment. Kluwer Academic Publishers, The Netherlands, pp 347-366.

Cosentino SL, Copani V, D’Agosta GM, Sanzone E, Mantineo M, 2006. First results on evaluation of Arundo donax L. clones collected in Southern Italy. Ind. Crop. Prod. 23:212-22.

Cosentino SL, Patanè C, Sanzone E, Testa G, Scordia D, 2016. Leaf gas exchange, water status and radiation use efficiency of giant reed (Arundo donax L.) in a changing soil nitrogen fertilization and soil water availability in a semi-arid Mediterranean area. Eur. J. Agron. 72:56-69.

De Pascale S, Ruggiero C, Barbieri G, 1999. Risposta fisiologica del fagiolino da industria all'irrigazione con acque saline. Riv. Agr. 2:79-89.

De Pascale S, Maggio A, Barbieri G, 2005. Soil salinization affects growth, yield and mineral composition of cauliflower and broccoli. Eur. J. Agron. 23:254-64.

Duce P, 2005. Progetto Climagri-cambiamenti climatici e agricoltura, risultati $1^{\circ}$ anno: individuazione delle aree agricole e delle colture a forte rischio per variazioni climatiche. Available from: http://www.climagri.it/FinaleDUCE.htm\#ancora

Fagnano M, Impagliazzo A, Mori M, Fiorentino N, 2015. Agronomic and environmental impacts of giant reed (Arundo donax L.): results from a long-term field experiment in hilly areas subject to soil erosion. Bioenerg. Res. 8:415-22.

Fiorentino N, Impagliazzo A, Ventorino V, Pepe O, Piccolo A, Fagnano M, 2010. Biomass accumulation and heavy metal uptake of giant reed on polluted soil in southern Italy. J. Biotechnol. 150:261.

Fiorentino N, Ventorino V, Rocco C, Cenvinzo V, Agrelli D, Gioia L, Di Mola I, Adamo P, Pepe O, Fagnano M, 2017. Giant reed growth and soil biological fertility in assisted phytoremediation of an industrial polluted soil. Sci. Total Environ. 575:1375-83.

Flexas J, Bota J, Loreto F, Cornic G, Sharkey TD, 2004. Diffusive and metabolic limitations to photosynthesis under drought and salinity in C3 plants. Plant Biol. 6:269-79.

Flexas J, Galmes J, Ribas-Carbo M, Medrano H, 2005. The effects of water stress on plant respiration. In: H. Lambers, M. RibasCarbo (Eds.), Plant respiration: from cell to ecosystem. Springer, Dordrecht, The Netherlands, pp 85-94.

Giorio P, Nuzzo V, Guida G, Albrizio R, 2011. Black leaf-clips increased minimum fluorescence emission in clipped leaves exposed to high solar radiation during dark adaptation. Photosynthetica 49:371-9.

Greenway H, Munns R, 1980. Mechanisms of salt tolerance in non-halophytes. Annu. Rev. Plant Phys. 31:149-90.

Impagliazzo A, Mori M, Fiorentino N, Di Mola I, Ottaiano L, De Gianni D, Nocerino S, Fagnano M, 2017. Crop growth analysis and yield of a lignocellulosic biomass crop (Arundo donax L.) 
in three marginal areas of Campania region. Ital. J. Agr. 12:1-7.

Jones HG, 1992. Plants and Microclimate. Cambridge University Press, Cambridge, New York, NY, USA.

Kitajima M, Butler WL, 1975. Quenching of chlorophyll fluorescence and primary photochemistry in chloroplasts by dibromothymoquinone. Biochim. Biophys. Acta 376:105-15.

Läuchli A, Epstein E, 1990. Plant response to salinity and sodic conditions. In: K.K. Tanji (Ed.), Agricultural salinity assessment and management. American Society of Civil Engineering, New York, USA, pp 113-137.

Lewandowski I, Scurlockb JMO, Lindvallc E, Christoud M, 2003. The development and current status of perennial rhizomatous grasses as energy crops in the US and Europe. Biomass Bioenerg. 25:335-61.

Li-Cor, 2011. Using the Li-6400/Li-6400XT portable photosynthesis system. Lincoln, NE, USA.

Longstreth DJ, Nobel PS, 1979. Salinity effects on leaf anatomy. Consequences for photosynthesis. Plant Physiol. 63:700-703.

Maas EV, Hoffman GJ, 1977. Crop salt tolerance - current assessment. J. Irrig. Drain. Divis. 103:115-34.

Maas EV, 1986. Salt tolerance of plants. Appl. Agric. Res. 1:12-26.

Maas EV, Grattan SR, 1999. Crop yields as affected by salinity. In: R.W. Skaggs and J. van Schilfgaarde (Eds.), Agriculture drainage. Agron. Monograph. N³8, ASA, Madison, WI, USA, pp. 55-108.

Mann JJ, Barney JN, Kyser GB, Di Tomaso, JM, 2013. Miscanthus $\times$ giganteus and Arundo donax shoot and rhizome tolerance of extreme moisture stress. GCB Bioenergy 5:693-700.

Mantineo M, D'Agosta GM, Copani V, Patanè C, Cosentino SL, 2009. Biomass yield and energy balance of three perennial crops for energy use in the semi arid Mediterranean environment. Field Crop Res. 114:204-13.

Mori M, Amato M, Di Mola I, Caputo R, Quaglietta Chiarandà F, Di Tommaso T, 2008. Productive behaviour of "cherry"-type tomato irrigated with saline water in relation to nitrogen fertilization. Eur. J. Agron. 29:135-43.

Mori M, Di Mola I, Quaglietta Chiarandà F, 2011. Salt stress and transplant time in snap bean: growth and productive behaviour. Int. J. Plant Prod. 5:49-64.

Morse HN, 1914. The osmotic pressure of aqueous solutions: report on investigations made in the chemical laboratory of the Johns Hopkins University during the Years 1899-1913. Publication number 198. Carnegie Institute, Washington, DC, USA.

Munns R, Termaat A, 1986. Whole-plant response to Salinity. Aust. J. Plant Physiol. 13:143-60.

Nackley LL, Kim SH, 2015. A salt on the bioenergy and biological invasions debate: salinity tolerance of the invasive biomass feedstock Arundo donax. GCB Bioenergy 7:752-62.

Nassi o Di Nasso N, Roncucci N, Triana F, Tozzini C, Bonari E, 2011. Productivity of giant reed (Arundo donax L.) and miscanthus (Miscanthus x giganteus Greef et Deuter) as energy crops: Growth analysis. Ital. J. Agr. 6:141-7.

Patel RM, Prashera SO, Donnelly D, Bonnell RB, 2001. Effect of initial soil salinity and subirrigation water salinity on potato tuber yield and size. Agr. Water Manage. 46:231-9.

Pompeiano A, Guglielminetti L, Bargiacchi E, Miele S. 2013. Responses in chemical traits and biomass allocation of Arundo donax L. to deficit resources in the establishment year. Chil. J. Agric. Res. 73:377-84.

Pompeiano A, Landi M, Meloni G, Vita F, Guglielminetti L, Guidi L, 2017. Allocation pattern, ion partitioning, and chlorophyll a fluorescence in Arundo donax L. in responses to salinity stress.
Plant Biosyst. 151:613-22.

Rossa B, Tuffers AV, Von WDJ, 1998. Arundo donax L. (Poaceae) - a C3 species with unusually high photosynthetic capacity. Bot. Acta 111:216-21.

Sánchez E, Scordia D, Lino G, Arias C, Cosentino SL, Nogués S, 2015. Salinity and water stress effects on biomass production in different Arundo donax L. Clones. Bioener. Res. 8:1461-79.

Shahbaz M, Ashraf M, Al-Qurainy F, Harris PJC, 2012. Salt tolerance in selected vegetable crops. Crit. Rev. Plant Sci. 31:30320.

Sharma KP, Kushwaha SPS, Gopal B, 1998. A comparative study of stand structure and standing crops of two wetland species, Arundo donax and Phragmites karka, and primary production in Arundo donax with observations on the effect of clipping. Trop. Ecol. 39:3-14.

Smith P, Olesen JE, 2010. Synergies between the mitigation of, and adaptation to, climate change in agriculture. J. Agr. Sci. 148: 543-52.

Sneha S, Rishi A, Chandra S, 2014. Effect of short term salt stress on chlorophyll content, protein and activities of catalase and ascorbate peroxidase enzymes in pearl millet. Am. J. Plant Physiol. 9:32-7.

Sonmez S, Buyuktas D, Okturen F, Citak S, 2008. Assessment of different soil to water ratios $(1: 1,1: 2.5,1: 5)$ in soil salinity studies. Geoderma 144:361-9.

Spencer DF, Ksander GG, Whitehand LC, 2005. Spatial and temporal variation in RGR and leaf quality of a clonal riparian plant: Arundo donax. Aquat. Bot. 81:27-36.

Strasser R, Srivastava A, Tsimilli-Michael M, 2000. The fluorescence transient as a tool to characterize and screen photosynthetic samples. In: M. Yunus, U. Pathre, P. Mohanty (Eds.), Probing photosynthesis: mechanisms, regulation and adaptation. Taylor \& Francis, London, UK, pp 445-483.

Tang A-C, Boyer JS, 2007. Leaf shrinkage decreases porosity at low water potentials in sunflower. Funct. Plant Biol. 34:24-30.

Triana F, Nassi o Di Nasso N, Ragaglini G, Roncucci N, Bonari E, 2015. Evapotranspiration, crop coefficient and water use efficiency of giant reed (Arundo donax L.) and miscanthus (Miscanthus 3 giganteus Greef et Deu.) in a Mediterranean environment. GCB Bioenergy 7:811-9.

von Caemmerer S, Farquhar GD, 1981. Some relationships between the biochemistry of photosynthesis and the gas exchange of leaves. Planta 153:376-87.

Yeo A, 1998. Predicting the interaction between the effects of salinity and climate change on crop plants. Sci. Hortic. 78:15974.

Webster RJ, Driever SM, Kromdijk J, McGrath J, Leakey AD, Siebke K, Demetriades-Shah T, Bonnage S, Peloe T, Lawson T, Long SP, 2016. High C3 photosynthetic capacity and high intrinsic water use efficiency underlies the high productivity of the bioenergy grass Arundo donax. Sci. Rep. 6:20694.

Williams CMJ, Biswas TK, Schrale G, Virtue JG, Heading S, 2008. Use of saline land and wastewater for growing a potential biofuel crop (Arundo donax L.). Irrigation Australia 2008 Conference, Melbourne, Australia.

Williams CMJ, Biswas TK, Black ID, Marton L, Czako M, Harris PL, Pollok R, Heading S, Virtue JG, 2009. Use of poor quality water to produce high biomass yields of giant reed (Arundo donax L.) on marginal lands for biofuel or pulp/paper. Acta Hortic. 806:595-602 